\title{
A Critical Re-Evaluation of the $\mathrm{O}-\mathrm{H}$ bond
}

\section{Dissociation Enthalpy in Phenol}

Peter Mulder, ${ }^{\#, *}$ Hans-Gert Korth, ${ }^{£}$ Derek A. Pratt, ${ }^{\S}$ Gino A. DiLabio, ${ }^{\#}$ Luca Valgimigli, ${ }^{\ddagger}$

\author{
G. F. Pedulli and K. U. Ingold ${ }^{\natural}$
}

Institute of Chemistry, Leiden University, PO Box 9502, 2300 RA Leiden, The Netherlands; Institut für Organische Chemie, Universität Duisburg-Essen, D-45117 Essen, Germany; University of Illinois at Urbana-Champaign, Urbana, IL 61801, USA; National Institute for Nanotechnology, National Research Council of Canada, W6-010 ECERF, $9107116^{\text {th }}$ Street, Edmonton, Canada T6G 2V4; Dipartimento di Chimica Organica “A. Mangini”, Università degli Studi di Bologna, Via S. Donato 15, 40127 Bologna, Italy, and the National Research Council of Canada, 100 Sussex Drive, Ottawa, ON K1A 0R6, Canada

\footnotetext{
${ }^{¥}$ Leiden University

${ }^{£}$ Universität Duisburg-Essen

${ }^{\S}$ University of Illinois

\# National Institute for Nanotechnology

‡ Università degli Studi di Bologna

\& National Research Council of Canada

e-mail: p.mulder@chem.leidenuniv.nl
} 
Table S1: Computed and experimental $\Delta_{\mathrm{f}} \mathrm{Hs}$ in $\mathrm{kcal} \mathrm{mol}^{-1}$ at $298 \mathrm{~K}^{a}$

\begin{tabular}{|c|c|c|c|c|}
\hline & G3 & CBS-APNO & CBS-QB3 & $\Delta_{\mathrm{f}} H_{\exp }^{b}$ \\
\hline $\mathrm{CH}_{3} \mathrm{OH}$ & $-48.1(0.0)$ & $-48.9(-0.8)$ & $-48.9(-0.8)$ & $-48.07 \pm 0.05$ \\
\hline $\mathrm{CH}_{3} \mathrm{OCH}_{3}$ & $-44.4(-0.4)$ & $-45.9(-1.9)$ & $-45.4(-1.4)$ & $-43.99 \pm 0.15$ \\
\hline $\mathrm{C}_{6} \mathrm{H}_{5} \mathrm{OH}$ & $-22.0(+1.0)$ & $-24.8(-1.8)$ & $-21.6(+1.4)$ & $-23.03 \pm 0.14$ \\
\hline $\mathrm{C}_{6} \mathrm{H}_{5} \mathrm{OCH}_{3}$ & $-17.3(+1.0)$ & $-20.7(-2.4)$ & $-16.8(+1.5)$ & $-18.33 \pm 0.25$ \\
\hline $\mathrm{C}_{6} \mathrm{H}_{5} \mathrm{OC}_{6} \mathrm{H}_{5}$ & n.a. & n.a. & n.a. & $12.4 \pm 0.3^{c}$ \\
\hline $\mathrm{CH}_{4}$ & $-18.2(-0.4)$ & $-18.9(-1.1)$ & $-17.8(0.0)$ & $-17.8 \pm 0.1$ \\
\hline $\mathrm{C}_{2} \mathrm{H}_{6}$ & $-20.4(0.0)$ & $-21.8(-1.4)$ & $-19.8(+0.6)$ & $-20.4 \pm 0.07$ \\
\hline $\mathrm{C}_{3} \mathrm{H}_{8}$ & $-25.3(-0.3)$ & $-27.4(-2.4)$ & $-24.4(+0.6)$ & $-25.02 \pm 0.12$ \\
\hline $\mathrm{C}_{6} \mathrm{H}_{5} \mathrm{CH}_{3}$ & $12.4(+0.5)$ & $8.9(-3.1)$ & $13.7(+1.8)$ & $11.95 \pm 0.15$ \\
\hline $\mathrm{C}_{6} \mathrm{H}_{5} \mathrm{CH}_{2} \mathrm{CH}_{3}$ & $8.0(+0.9)$ & $4.0(-3.1)$ & $8.8(+1.7)$ & $7.12 \pm 0.2$ \\
\hline $\mathrm{H}^{\bullet}$ & $52.1(0.0)$ & $52.1(0.0)$ & $52.1(0.0)$ & $52.103 \pm 0.003$ \\
\hline $\mathrm{C}$ & $171.2(-0.1)$ & $171.2(-0.1)$ & $171.2(-0.1)$ & $171.29 \pm 0.11$ \\
\hline $\mathrm{O}$ & $59.4(-0.2)$ & $59.4(-0.2)$ & $59.4(-0.2)$ & $59.555 \pm 0.024$ \\
\hline $\mathrm{CH}_{3} \cdot$ & $34.0(-1.1)$ & $34.4(-0.6)$ & $35.5(+0.5)$ & $35.05 \pm 0.07$ \\
\hline $\mathrm{C}_{2} \mathrm{H}_{5}^{\cdot}$ & $28.7(-0.3)$ & $27.9(-1.1)$ & $29.8(+0.8)$ & $29.0 \pm 0.4^{d}$ \\
\hline $\mathrm{CH}_{3} \mathrm{O}^{\bullet}$ & $4.9(+0.6)$ & $4.3(0.0)$ & $4.3(0.0)$ & $4.3 \pm 0.7$ \\
\hline $\mathrm{C}_{6} \mathrm{H}_{5} \mathrm{O}^{\bullet}$ & $14.1(+2.5)$ & $11.3(-0.3)$ & $13.4(+1.8)$ & $11.6 \pm 0.7^{e}$ \\
\hline $\mathrm{C}_{6} \mathrm{H}_{5} \mathrm{CH}_{2}{ }^{\cdot}$ & $50.8(+1.1)$ & $48.2(-1.5)$ & $52.2(+2.5)$ & $49.7 \pm 0.6$ \\
\hline
\end{tabular}

${ }^{a}$ In parenthesis: $\Delta H_{\mathrm{f} \text { comp }}-\Delta H_{\mathrm{fexp}}{ }^{b}$ Ref 18 , unless otherwise indicated. ${ }^{c}$ Ref $20 .{ }^{d} \operatorname{Ref} 2$.

${ }^{e}$ Derived from BDE(O-H) in phenol of $86.7 \pm 0.7 \mathrm{kcal} \mathrm{mol}^{-1}$, see Table 4 . 
Table S2. CBS-QB3 Energies in kcal $\mathrm{mol}^{-1}$

\begin{tabular}{ccccccc}
\hline Reaction & Property & $\Delta E(0 \mathrm{~K})$ & $\begin{array}{c}\Delta E(0 \mathrm{~K}) \\
+\mathrm{ZPVE}\end{array}$ & $\Delta E(298 \mathrm{~K})$ & $\Delta H(298 \mathrm{~K})$ & $\Delta G(298 \mathrm{~K})$ \\
\hline $\mathrm{PhO}^{-}+\mathrm{H}^{+} \rightarrow \mathrm{PhOH}$ & $\Delta_{\text {acid }} H\left(\mathrm{C}_{6} \mathrm{H}_{5} \mathrm{OH}\right)$ & 356.84 & 348.01 & 347.89 & 348.72 & 349.41 \\
$\mathrm{PhO}^{\bullet}+e^{-} \rightarrow \mathrm{PhO}^{-}$ & $E A\left(\mathrm{C}_{6} \mathrm{H}_{5} \mathrm{O}^{\bullet}\right)$ & 50.71 & 51.40 & 51.35 & 51.41 & 50.95 \\
$\mathrm{H}^{\bullet} \rightarrow \mathrm{H}^{+}+e^{-}$ & $I P\left(\mathrm{H}^{\bullet}\right)$ & 313.64 & 313.64 & 312.75 & 313.05 & 321.22 \\
$\mathrm{PhOH} \rightarrow \mathrm{PhOH}^{+}+e^{-}$ & $I P\left(\mathrm{C}_{6} \mathrm{H}_{5} \mathrm{OH}\right)$ & 197.43 & 197.46 & 197.48 & 197.48 & 185.33 \\
$\mathrm{PhOH}^{+} \rightarrow \mathrm{PhO}^{\bullet}+\mathrm{H}^{+}$ & $P A\left(\mathrm{C}_{6} \mathrm{H}_{5} \mathrm{O}^{\bullet}\right)$ & 210.12 & 201.95 & 201.77 & 202.66 & 203.32 \\
$\mathrm{PhOH} \rightarrow \mathrm{PhO}^{\bullet}+\mathrm{H}^{\bullet}$ & $\mathrm{O}-\mathrm{H} \mathrm{BDE}^{-9}$ & 93.91 & 85.77 & 86.49 & 87.09 & 79.15 \\
\hline
\end{tabular}




\section{On the gas-phase heat of formation of anisole, $\Delta_{\mathrm{f}} \mathrm{H}\left(\mathrm{C}_{6} \mathrm{H}_{5} \mathrm{OCH}_{3}\right)^{\text {gas }}$}

Currently two values for the $\Delta_{\mathrm{f}} H\left(\mathrm{C}_{6} \mathrm{H}_{5} \mathrm{OCH}_{3}\right)^{\text {gas }}$ are available, i.e. $-16.24 \pm 0.29$ and $-18.33 \pm 0.22 \mathrm{kcal} \mathrm{mol}^{-1} .{ }^{18}$

A. Direct calorimetric determination. Three studies have reported ${ }^{18}$ the heat of combustion of liquid anisole as -903.2 (1941), -902.9 (1972), and -904.19 (1975) kcal mol ${ }^{-1}$, yielding a $\Delta_{\mathrm{f}} H\left(\mathrm{C}_{6} \mathrm{H}_{5} \mathrm{OCH}_{3}\right)^{\text {liq }}$ of $-28.3,-28.7 \pm 0.2$, and $-27.4 \pm 0.3 \mathrm{kcal} \mathrm{mol}^{-1}$. The measured enthalpy of vaporization, $\Delta_{\mathrm{v}} H$, has been reported three times: 9.42 (1957), $9.1 \pm 0.1$ (1972), and 11.20 \pm 0.05 (1975) kcal mol ${ }^{-1}$. Thus, with an average (first two values) for $\Delta_{\mathrm{v}} H$ of 9.3, the $\Delta_{\mathrm{f}} H\left(\mathrm{C}_{6} \mathrm{H}_{5} \mathrm{OCH}_{3}\right)^{\text {gas }}$ becomes $-19.0,-19.40$, and $-18.10 \mathrm{kcal} \mathrm{mol}^{-1}$. On the other hand, with $\Delta_{\mathrm{v}} H$ of $11.2, \Delta_{\mathrm{f}} H\left(\mathrm{C}_{6} \mathrm{H}_{5} \mathrm{OCH}_{3}\right)^{\text {gas }}$ becomes $-17.1,-17.5$ and $-16.2 \mathrm{kcal} \mathrm{mol}^{-1}$.

A reanalysis of the 1972 data gave the $\Delta_{\mathrm{f}} H\left(\mathrm{C}_{6} \mathrm{H}_{5} \mathrm{OCH}_{3}\right)^{\text {gas }}=-18.33 \mathrm{kcal} \mathrm{mol}^{-1} \cdot{ }^{18,20}$

B. Application of increment rules. The $\Delta_{\mathrm{f}} \mathrm{Hs}$ for $1,4-\left(\mathrm{CH}_{3} \mathrm{O}\right)_{2} \mathrm{C}_{6} \mathrm{H}_{4}{ }^{a}$ and $4-\left(\mathrm{CH}_{3} \mathrm{O}\right) \mathrm{C}_{6} \mathrm{H}_{4} \mathrm{OH}^{b}$ are -50.6 and $-54.9 \mathrm{kcal} \mathrm{mol}^{-1}$, respectively. Hence, the increment in $\Delta_{\mathrm{f}} H$ for replacing $\mathrm{OH}$ by $\mathrm{OCH}_{3}$ is $4.3 \mathrm{kcal} \mathrm{mol}^{-1}$, quite similar to replacing of $\mathrm{OH}$ by $\mathrm{OCH}_{3}$ in $\mathrm{CH}_{3} \mathrm{OH} / \mathrm{CH}_{3} \mathrm{OCH}_{3}$ of $4.1 \mathrm{kcal} \mathrm{mol}{ }^{-1} .{ }^{18}$ With a $\Delta_{\mathrm{f}} H^{\text {gas }}$ for phenol of -23.03 , this yields a $\Delta_{\mathrm{f}} H\left(\mathrm{C}_{6} \mathrm{H}_{5} \mathrm{OCH}_{3}\right)^{\text {gas }}$ of $-23.03+4.3=-18.73 \mathrm{kcal} \mathrm{mol}^{-1}$. The experimental reaction enthalpy for eq $32, \Delta_{\mathrm{r}} H_{32}$, is 0.4 , when using $\Delta_{\mathrm{f}} H\left(\mathrm{C}_{6} \mathrm{H}_{5} \mathrm{OCH}_{3}\right)^{\text {gas }}=-18.33 \mathrm{kcal} \mathrm{mol}^{-1}$. Computations by B3LYP/6-31G(d,p)// B3LYP/6-31G(d,p) yields $\Delta_{\mathrm{r}} H_{32} 0.1 \mathrm{kcal} \mathrm{mol}^{-1}$.

$4-\mathrm{CH}_{3} \mathrm{OC}_{6} \mathrm{H}_{4} \mathrm{OCH}_{3}+\mathrm{C}_{6} \mathrm{H}_{5} \mathrm{OH} \longrightarrow 4-\mathrm{CH}_{3} \mathrm{OC}_{6} \mathrm{H}_{4} \mathrm{OH}+\mathrm{C}_{6} \mathrm{H}_{5} \mathrm{OCH}_{3}$

In conclusion, all features presented support the literature value for $\Delta_{\mathrm{f}} H\left(\mathrm{C}_{6} \mathrm{H}_{5} \mathrm{OCH}_{3}\right)^{\text {gas }}$ of $-18.33 \mathrm{kcal} \mathrm{mol}^{-1}$.

\footnotetext{
${ }^{a}$ Matos, M. A. R.; Miranda, M. S.; Morias, V. M. F. J. Phys. Chem. A 2000, 104, 92609265. ${ }^{b}$ Matos, M. A. R.; Miranda, M. S.; Morias, V. M. F. J. Chem. Eng. Data 2003, 48, 669-679.
} 


\section{Hydrogen bonding between phenol and various solvents including di-tert-} butyl peroxide

Table S3. Parameters for the hydrogen bond equilibrium (eq 18): $\mathrm{PhOH}+\mathrm{A} \rightleftharpoons$ $\mathrm{PhOH}_{\mathrm{HB}}$ in the pure liquid

\begin{tabular}{cccccc}
\hline A & $\mathrm{M}$ & $\beta_{2}^{\mathrm{H} a}$ & $K_{18}{ }^{c}$ & $\begin{array}{c}\mathrm{PhOH}_{\mathrm{HB}} / \\
\mathrm{PhOH}_{\mathrm{o}}{ }^{d}\end{array}$ & $\Delta_{\mathrm{r}} \mathrm{H}_{18}{ }^{e}$ \\
\hline isooctane & 6.07 & 0 & 0 & 0 & 0 \\
benzene & 11.26 & 0.15 & 0.366 & 0.805 & -1.24 \\
ethyl acetate & 10.23 & 0.45 & 7.557 & 0.987 & -4.92 \\
di-tert-butyl peroxide & 5.43 & $0.33^{b}$ & 2.251 & 0.924 & $-2.72^{f}$ \\
\hline
\end{tabular}

${ }^{a}$ Hydrogen bond basicity from ref. 31a. ${ }^{b}$ Ref. $31 \mathrm{~b}$, and this work, see text. ${ }^{c}$ Equilibrium constant according to eq 20 and using $\alpha_{2}^{\mathrm{H}}$ (phenol) $=0.596 .{ }^{d}$ Hydrogen bonded phenol, $\mathrm{PhOH}_{\mathrm{HB}}$, relative to the initial amount of phenol, $\mathrm{PhOH}_{\mathrm{o}}$, dissolved in the pure liquid. ${ }^{e}$ Enthalpy for the hydrogen bonding equilibrium, $\Delta_{\mathrm{r}} \mathrm{H}_{18}$, when dissolving phenol in the pure liquid according to eq $22 .{ }^{f}$ For the calculation of $\Delta_{\mathrm{r}} H_{18}$ for di-tert-butyl peroxide, the statistical correction factor of two has been employed leading to $\beta_{2}^{\mathrm{H}}=0.27$.

Table S4. $\Delta_{\mathrm{r}} H\left(\right.$ in $\mathrm{kcal} \mathrm{mol}^{-1}$ ) for $\mathrm{PhOH}+\mathrm{A} \rightleftharpoons \mathrm{PhOH}_{\mathrm{HB}}($ eq 18) in binary solvent systems $^{a}$

\begin{tabular}{ccccccc}
\hline $\begin{array}{c}\text { vol } \\
(\%)\end{array}$ & $\begin{array}{c}\text { isooctane (a) } \\
(\mathrm{M})\end{array}$ & $\begin{array}{c}\text { vol } \\
(\%)\end{array}$ & $\begin{array}{c}\text { di-tert-butyl } \\
\text { peroxide }(\mathrm{b}) \\
(\mathrm{M})\end{array}$ & $\Delta_{\mathrm{r}} H_{18}(\mathrm{a})$ & $\Delta_{\mathrm{r}} H_{18}(\mathrm{~b})$ & $\Delta_{\mathrm{r}} H_{18}$ \\
\hline 100 & 6.07 & 0 & 0 & 0 & 0 & 0 \\
95 & 5.76 & 5 & 0.27 & 0 & -0.40 & -0.40 \\
90 & 5.46 & 10 & 0.54 & 0 & -0.72 & -0.72 \\
85 & 5.16 & 15 & 0.82 & 0 & -0.99 & -0.99 \\
\hline & & & & & & \\
\hline vol & benzene (a) & vol & $\begin{array}{c}\text { di-tert-butyl } \\
\text { peroxide }(\mathrm{b})\end{array}$ & $\Delta_{\mathrm{r}} H_{18}(\mathrm{a})$ & $\Delta_{\mathrm{r}} H_{18}(\mathrm{~b})$ & $\Delta_{\mathrm{r}} H_{18}$ \\
$(\%)$ & $(\mathrm{M})$ & $(\%)$ & $(\mathrm{M})$ & & & \\
\hline 100 & 11.26 & 0 & 0 & -1.24 & 0 & -1.24 \\
95 & 10.70 & 5 & 0.27 & -1.10 & -0.32 & -1.42 \\
90 & 10.14 & 10 & 0.54 & -0.97 & -0.61 & -1.58 \\
85 & 9.57 & 15 & 0.82 & -0.86 & -0.85 & -1.71 \\
\hline
\end{tabular}




\begin{tabular}{ccccccc}
\hline $\begin{array}{c}\text { vol } \\
(\%)\end{array}$ & $\begin{array}{c}\text { ethyl acetate (a) } \\
(\mathrm{M})\end{array}$ & $\begin{array}{c}\text { vol } \\
(\%)\end{array}$ & $\begin{array}{c}\text { di-tert-butyl } \\
\text { peroxide }(\mathrm{b}) \\
(\mathrm{M})\end{array}$ & $\Delta_{\mathrm{r}} H_{18}(\mathrm{a})$ & $\Delta_{\mathrm{r}} H_{18}(\mathrm{~b})$ & $\Delta_{\mathrm{r}} H_{18}$ \\
\hline 100 & 10.23 & 0 & 0 & -4.92 & 0 & -4.92 \\
95 & 9.72 & 5 & 0.27 & -4.88 & -0.02 & -4.90 \\
90 & 9.21 & 10 & 0.54 & -4.83 & -0.05 & -4.88 \\
85 & 8.70 & 15 & 0.82 & -4.78 & -0.08 & -4.86 \\
\hline
\end{tabular}

${ }^{a} \Delta_{\mathrm{r}} H_{18}(\mathrm{a})$ and $\Delta_{\mathrm{r}} H_{18}(\mathrm{~b})$ are the individual hydrogen bond enthalpies for the interaction of phenol with solvent a or b. For each solvent mixture the $\mathrm{PhOH}_{\mathrm{HB}(\mathrm{a})} / \mathrm{PhOH}_{\mathrm{o}}$ and $\mathrm{PhOH}_{\mathrm{HB}(\mathrm{b})} / \mathrm{PhOH}_{\mathrm{o}}$ ratios are computed; with the auxilary data from Table $\mathrm{S} 3, \Delta_{\mathrm{r}} H_{18}$ (a) and $\Delta_{\mathrm{r}} H_{18}(\mathrm{~b})$ are derived, and $\Delta_{\mathrm{r}} H_{18}=\Delta_{\mathrm{r}} H_{18}(\mathrm{a})+\Delta_{\mathrm{r}} H_{18}(\mathrm{~b})$. 


\section{Computational solvent models}

The SM5.42R ${ }^{a}$ and PCM-UAHF ${ }^{b}$ solvent models were chosen because they are computationally inexpensive, and SM5.42R has given good agreement with experiment in a similar type of dipole/solvent interaction problem, ${ }^{c}$ and with PCM-UAHF good linear correlations $\left(r^{2} \geq 0.99\right)$ with experimental solvation free energies from various sources were found. ${ }^{d}$

Table S5. Computed and experimental energies of solvation for relevant species in water in $\mathrm{kcal} \mathrm{mol}^{-1}$ at $298 \mathrm{~K}$

\begin{tabular}{cccccc}
\hline & $\begin{array}{c}\mathrm{SM} 5.42 \mathrm{R}^{1} \\
\Delta_{\text {solv }} G^{\mathrm{aq}}\end{array}$ & $\begin{array}{c}\mathrm{PCM}-\mathrm{UAHF}^{l} \\
\Delta_{\text {solv }} G^{\mathrm{aq}}\end{array}$ & $\begin{array}{c}\operatorname{Exp}^{2} \\
\text { solv } G^{\text {aq }}\end{array}$ & $\begin{array}{c}\text { Monte-Carlo } \\
\Delta_{\text {solv }} H^{\text {aq }}\end{array}$ & $\begin{array}{c}\mathrm{Eq} 22 \\
\Delta_{\mathrm{r}} H^{\text {aq }}\end{array}$ \\
\hline $\mathrm{C}_{6} \mathrm{H}_{5} \mathrm{OH}$ & -6.9 & -7.9 & -6.62 & $-18.6(-13.4)$ & -4.1 \\
$\mathrm{C}_{6} \mathrm{H}_{5} \mathrm{O}$ & -6.8 & -4.7 & & -10.6 & -2.9 \\
$\mathrm{C}_{6} \mathrm{H}_{5} \mathrm{OMe}$ & -3.5 & -3.9 & -2.45 & & -1.3 \\
\hline
\end{tabular}

${ }^{1}$ SM5.42R on AM1 geometry, PCM-UAHF (U)HF/6-31G(d) basis set on B3LYP/6$311 \mathrm{G}(2 \mathrm{~d}, \mathrm{~d}, \mathrm{p})$ geometry. ${ }^{2}$ Experimental $\Delta_{\text {solv }} G^{\text {aq }}$ see ref. a. ${ }^{3}$ From ref. 38 , experimentally determined $\Delta_{\text {solv }} H^{\text {aq }}$ in parenthesis.

For the molecules, i.e. phenol and ansisole, the $\Delta_{\text {solv }} G^{\text {aq }}$ values are in reasonable agreement with the experiment, and the differences in free energy of solvation, $\Delta \Delta_{\text {solv }} G\left(\mathrm{C}_{6} \mathrm{H}_{5} \mathrm{OH}-\right.$ $\left.\mathrm{C}_{6} \mathrm{H}_{5} \mathrm{OMe}\right)^{\mathrm{aq}}$ are -3.4 (SM5.42R), -4.0 (PCM-UAHF), and -4.17 (exp.) kcal mol ${ }^{-1}$, which may be associated with the variation of the hydrogen bond strength for phenol and anisole with the solvent water. According to eq $22, \Delta \Delta_{\text {solv }} H\left(\mathrm{C}_{6} \mathrm{H}_{5} \mathrm{OH}-\mathrm{C}_{6} \mathrm{H}_{5} \mathrm{OMe}\right)^{\mathrm{aq}}$ is $-4.1-(-1.3)=$ $-2.8 \mathrm{kcal} \mathrm{mol}^{-1}$ (Table S5). For the phenol and phenoxyl couple, and in the unlikely event that $\Delta \Delta_{\text {solv }} S\left(\mathrm{C}_{6} \mathrm{H}_{5} \mathrm{OH}-\mathrm{C}_{6} \mathrm{H}_{5} \mathrm{O}^{\bullet}\right)^{\mathrm{aq}} \approx 0$, (i.e. $\left.\Delta \Delta_{\text {solv }} G^{\mathrm{aq}} \approx \Delta \Delta_{\text {solv }} H^{\mathrm{aq}}\right)$, it becomes clear that hydrogen bonding considerations alone do not account for the solvation energy differences found by theory. The SM5.42R data imply that the corrections for solvation of $\mathrm{C}_{6} \mathrm{H}_{5} \mathrm{OH}$ and $\mathrm{C}_{6} \mathrm{H}_{5} \mathrm{O}{ }^{\circ}$, $\Delta \Delta_{\text {solv }} G\left(\mathrm{C}_{6} \mathrm{H}_{5} \mathrm{OH}-\mathrm{C}_{6} \mathrm{H}_{5} \mathrm{O}^{\bullet}\right)^{\text {aq }}$, virtually cancel one another, while PCM-UAHF predicts -3.2 , which is considerable greater than the value of $\left.\Delta \Delta_{\text {solv }} H\left(\mathrm{C}_{6} \mathrm{H}_{5} \mathrm{OH}-\mathrm{C}_{6} \mathrm{H}_{5} \mathrm{O}\right)^{\bullet}\right)^{\mathrm{aq}}$ of $-1.2 \mathrm{kcal}$ $\mathrm{mol}^{-1}$ which is derived from eq 22 (see Table S5). Since theoretical approaches yield widely different results for $\Delta \Delta_{\text {solv }} G\left(\mathrm{C}_{6} \mathrm{H}_{5} \mathrm{OH}-\mathrm{C}_{6} \mathrm{H}_{5} \mathrm{O}\right)^{\bullet}$ aq it is clear that a more trustworthy computational method would be welcome.

\footnotetext{
${ }^{a}$ Li, J.; Zhu. T.; Hawkins, G. D.; Winget, P.; Liotard, D. A.; Cramer, C. J.; Truhlar, D. G. Theor. Chem. Acc., 1999, 103, 9-63. Implemented in: AMSOL Version 6.9 Hawkins, G. D.; Giesen, D. J.; Lynch, G. C.; Chambers, C. C.; Rossi, I.; Storer, J. W.; Li, J.; Zhu, T.; Thompson, J. D.; Winget, P.; Rinaldi, D.; Liotard, D. A.; Cramer, C. J.; Truhlar, D. G. Regents of the University of Minnesota, 2003. ${ }^{b}$ PCM-UAHF ((U)HF/6-31G(d) basis set) is implemented in Gaussian 98, see: Barone, V.; Cossi, M.; Tomasi, J. J. Chem. Phys. 1997, 107, 3210-3221. ${ }^{c}$ DiLabio, G. A.; Ingold, K. U. J. Org. Chem. 2004, 69, 1620-1624. ${ }^{d}$ Korth, H.-G., unpublished observations.
} 